\title{
"Impact of the participatory financing of international development projects on social capital of the local communities"
}

\author{
Yuriy Petrushenko iD https://orcid.org/0000-0001-9902-7577 \\ R http://www.researcherid.com/rid/C-1072-2018 \\ AUTHORS \\ Nadiya Kostyuchenko \\ Denys Smolennikov \\ Anna Vorontsova (D https://orcid.org/0000-0003-0603-3869 \\ R http://www.researcherid.com/rid/R-3313-2018
}

\begin{tabular}{|c|c|}
\hline ARTICLE INFO & $\begin{array}{l}\text { Yuriy Petrushenko, Nadiya Kostyuchenko, Denys Smolennikov and Anna } \\
\text { Vorontsova (2017). Impact of the participatory financing of international } \\
\text { development projects on social capital of the local communities. Problems and } \\
\text { Perspectives in Management, 15(3), 183-192. doi:10.21511/ppm.15(3-1).2017.02 }\end{array}$ \\
\hline DOI & http://dx.doi.org/10.21511/ppm.15(3-1).2017.02 \\
\hline RELEASED ON & Friday, 27 October 2017 \\
\hline RECEIVED ON & Friday, 01 September 2017 \\
\hline \multirow[t]{2}{*}{ ACCEPTED ON } & Monday, 02 October 2017 \\
\hline & $(c c)$ EY-NC \\
\hline LICENSE & $\begin{array}{l}\text { This work is licensed under a Creative Commons Attribution-NonCommercial } 4.0 \\
\text { International License }\end{array}$ \\
\hline JOURNAL & "Problems and Perspectives in Management" \\
\hline ISSN PRINT & $1727-7051$ \\
\hline ISSN ONLINE & $1810-5467$ \\
\hline PUBLISHER & LLC "Consulting Publishing Company "Business Perspectives" \\
\hline FOUNDER & LLC "Consulting Publishing Company "Business Perspectives" \\
\hline & ニシ: \\
\hline NUMBER OF REFERENCES & NUMBER OF FIGURES \\
\hline 19 & 0 \\
\hline
\end{tabular}

(C) The author(s) 2022. This publication is an open access article. 


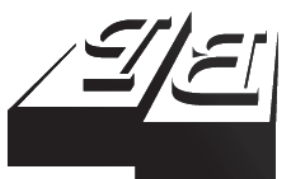

BUSINESS PERSPECTIVES

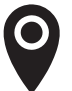

LLC "CPC "Business Perspectives" Hryhorii Skovoroda lane, 10, Sumy, 40022, Ukraine

www.businessperspectives.org

Received on: $1^{\text {st }}$ of September, 2017 Accepted on: $2^{\text {nd }}$ of October, 2017

(C) Yuriy Petrushenko, Nadiya Kostyuchenko, Denys Smolennikov, Anna Vorontsova, 2017

Yuriy Petrushenko, Doctor of Science (D.Sc.), Professor at the Department of International Economics, Sumy State University, Ukraine.

Nadiya Kostyuchenko, Ph.D. Associate Professor at the Department of Economic Theory, Sumy State University, Ukraine.

Denys Smolennikov, Assistant Professor at the Department of Management, Sumy State University, Ukraine.

Anna Vorontsova, PhD student at Department of International Economics, Sumy State University, Ukraine.

\section{(ㄷ)(1) (8)}

This is an Open Access article, distributed under the terms of the Creative Commons Attribution-NonCommercial 4.0 International license, which permits re-use, distribution, and reproduction, provided the materials aren't used for commercial purposes and the original work is properly cited.
Yuriy Petrushenko (Ukraine), Nadiya Kostyuchenko (Ukraine), Denys Smolennikov (Ukraine), Anna Vorontsova (Ukraine)

\section{IMPACT OF THE PARTICIPATORY FINANCING OF INTERNATIONAL DEVELOPMENT PROJECTS ON SOCIAL CAPITAL OF THE LOCAL COMMUNITIES}

\begin{abstract}
To date, the promotion of local development of the territorial communities by means of the financial policy tools is one of the priority directions of scientific research not only in Ukraine, but also throughout the world. The article presents the results of the study of the impact of the participatory financing (attraction of the financial resources of community members, central and local budgets and the international donors) on the social capital of the territorial communities of Sumy region on the basis of the results of two phases of the project "Community-based Approach to Local Development", which has been implemented in Ukraine by the United Nations Development Program since 2007. The main purpose of the article is to confirm the hypothesis that the participatory financing contributes to the social mobilization of the community residents, which leads to the activation of the "dormant" potential of collective actions and the desire of people to help themselves, as well as to improve some indicators of social capital. The difference-in-differences method and the multivariate regression analysis were used for the study. According to the results of the study, the characteristics of social capital, such as (anti)paternalism, the presence of traditions in community, involvement in social activities, collective action and cooperation are the most affected by the impact of participatory financing.
\end{abstract}

\section{Keywords}

social capital, territorial community, international projects, local development, participatory financing, regression analysis

\section{JEL Classification R11, H72, Z13, C20}

\section{INTRODUCTION}

The market direction of reforms, which was chosen by Ukraine in 1991, has led to the destruction of existing elements of economic culture, a sharp change in social ideals and morality. However, certain social groups have not found their place in a market-oriented society yet, new social norms and values are rejected by members of these communities, including patterns of behavior that are socially declared. It is especially obvious in rural areas in Ukraine, where the level of paternalism is extremely high, people do not believe in their own strength and they continue to rely on state assistance while solving their personal problems. The social contradiction impeding the local development consists in the fact that trust in state institutions is extremely low.

All this leads to a rapid degradation of such communities, not only in economic, but also in social context. In particular, peasants living on the same territory often do not consider themselves as one community, they no longer have common goals and values and, accordingly, are not able 
to effectively manage common resources, which are available in big amount (from social infrastructure to municipal roads, lands, reservoirs). Besides, according to the latest surveys of sociologists more than $50 \%$ of the inhabitants of rural area of Ukraine consider themselves poor (the Ukrainian Centre for Economic and Political Studies named after Olexander Razumkov, 2016). As a result, the number of rural residents decreased by $2.5 \mathrm{mln}$. residents only during the first 20 years of independence, during this time, 348 rural territorial communities disappeared from the map of Ukraine (UNIAN Information Agency, 2011). All this had determined the need for a large-scale territorial reform aimed at creating the enlarged (unified) territorial communities, which has been implemented in Ukraine since 2015.

At the same time, the world experience of local development shows that not the enlargement of territorial communities, but the processes of strengthening the social activity of local citizens, their social mobilization to form an effective mechanism for getting out of this state. The enlargement of territorial communities without simultaneous stimulation of the development of their social capital can lead to even worse trends in their functioning.

\section{LITERATURE REVIEW}

Scientists paid attention to the economic potential of social mobilization only at the end of the 19th century when economists gave evidence to the enormous potential of joint collective actions and destroyed the myth that citizens were only the recipients of goods from the state. In 1864, Friedrich Wilhelm Raiffeisen (Germany) put forward the idea of creating cooperatives, which eventually became the world movement. His concept was based on self-help, self-management and personal responsibility.

Regarding the financial tools for stimulating local development, the development of financial policy tool aimed at poverty reduction and stimulation of social and economic development of territorial communities has been recognized by the world community as one of the priority areas of scientific research of the 21st century, which had their reflection, in particular, in Millennium Development Goals approved by the UN in 2000, in the program documents of the World Forum on Sustainable Development RIO + 20 "The Future We Want". The concept of microfinance was awarded the Nobel Peace Prize 2006 "for efforts for economic and social development from below", and the World Bank, in recent years, has significantly increased the funding of development projects that provide the participation of local communities.

The practice of a community-based approach to development that promotes social mobilization and economic cooperation (community-based development and community-driven development), its importance and positive results were discussed in the world scientific literature in the second half of the twentieth century by M. Olson (1965), G. Hardin (1968), and, in the XXI century, by G. Mansuri, V. Rao (2004), R. Chase and C. Holmemo (World Bank, 2005), S. Tanaka, J. Singh, D. Songco (2006), P. Dongier, J. V. Domelen, E. Ostrom, A. Ryan, W. Wakeman, M. Polski et al. (2011), T. F. Walker (2011). B. Butler, D. Pick, and K. Dayaram (2009) hightlighted that social capital is a factor for economic development of the region and the growth process.

P. Dongier et al. (2011) have identified the main reasons why the community-based approach should be the basis for any local development strategy. The first reason is that the community-based approach to local development includes various sectors of the economy, i.e., public organizations and local governments, the government, as well as the private sector. The market itself cannot ensure the necessary level of meeting the population needs, and the communitybased approach creates an effective complementarity of the public and private sectors in the process of creating public goods. The second reason is that this approach contributes to the development sustainability. These scientists also assert that an approach based on community engagement to local development increases the economic effectiveness of services, increasing asset utilization in such sectors as infrastructure, education, microfinance and the rational use of natural resources. The community-based approach to local development gives the right to vote while determining the development priorities in such groups, which, as a rule, are excluded from the decision-making process at the local level. 
S. Tanaka, J. Singh and D. Songco (2011) and N. Kumar (2003) gave the characteristic of the concept "community-driven development". P. Dongier et al. (2011) determined the main reasons why the community-driven development should form the basis of any strategy of local development. At the same time, K. Whiteside and P. Wassenich (2004) emphasized the limitations of this approach.

Many scientists investigated the effectiveness and features of national programs of local development based on community engagement. Among them J. D. Fearon, M. Humphreys, and J. M. Weinstein (2009) who analyzed the local community-driven development program. This program was being implemented in Northern Liberia during 2006-2008. They have reached the conclusion that the creation of new institutions at the local level had a positive impact on the ability of communities to cooperate, and this effect lasted even after the end of the program. J. Sara and T. Katz (1997) analyzed the water supply program in six countries of the world (Benin, Bolivia, Honduras, Indonesia, Pakistan, Uganda and Ethiopia) and confirmed the efficiency of the approach of envolvement of community into the decision-making process. The influence of rural communities' participation in the community-based development project on the performance of agricultural sustainability was analyzed by N. Kostyuchenko, Yu. Petrushenko, D. Smolennikov, Yu. Danko (2015). However, the methodological foundations of the practical implementation of the approach to local development by involving territorial communities and implanting this approach into the system of state policy of local development remain insufficiently developed.

Poverty reduction is often the goal of government reforms in undeveloped countries. However, world experience shows that problems of the local communities are slowly solved through such regulation. At the same time, if there are clear rules of the game, access to the information and appropriate resource support, the poor and vulnerable groups of the population that form the local community can effectively organize themselves to receive goods and services that are of their immediate priorities (Dongier et al., 2011).

The middle of the 20th century was marked by the implementation and promotion of the community development ideology in many cities of the USA, Great Britain, Germany and other European countries. This idea means the changes in the relations between average citizens and representatives of authorities and provides the participation of average citizens in decision-making relating to their lives. It starts with the principle that there is knowledge and experience in any society and if they are properly used, they can be aimed at collective action to achieve the desired goals of community development.

\section{METHODOLOGY: PART 1}

In Ukraine, the community-based approach was used by the United Nations Development Program within the implementation of the following projects: "Crimea Integration and Development Program" (1995-2007), "Program of Revival and Development" (2002-2007), "Municipal Governance and Sustainable Development Program" (2004-2007), "Community-based Approach to Local Development" (commenced in 2007). The results of the last project became the objects of our study on the impact of the participatory financing on the changes in social capital indicators in territorial communities.

The Phase I of the EU/UNDP project "Communitybased Approach to Local Development" commenced in December 2007 and had a budget of 13.3 million euros. Over 3.5 years of activity, this project helped more than 1,000 rural communities to improve living conditions by joint efforts and in partnership with local authorities. The Phase I of the project "Community-based Approach to Local Development" lasted until June 6, 2011.

According to the financial mechanism, the project "Community-based Approach to Local Development" provided small grants for implementation of the community micro-projects on the basis of the principle of self-help and within the cooperation of the public and private sector, where each partner should contribute its financial share to the development.

The mechanism of the participatory financing within the project program provided that the share of the cost of micro-projects is financed by community members (not less than 5\%), other expenditures are financed from the central and local budgets (45\%), the participation of the project "Community-based 
Approach to Local Development" formed approximately half of all contributions (50\%).

1,303 community projects were implemented within the Phase I of the project "Communitybased Approach to Local Development". The communities chose the priorities for their projects themselves by voting at the general meeting. Thus, $59 \%$ of the communities have implemented the energy-saving measures in rural schools, kindergartens and medical institutions, $21 \%$ have renovated outpatients' clinics/feldsher-midwife stations and purchased medical equipment; $15 \%$ of the communities laid out or repaired the water supply system; $4 \%$ of the projects were connected with the purchase of school buses; $1 \%$ of the projects were aimed at the natural environment preservation. The average cost of the community project was about UAH 150 thousand (www.cba.org.ua).

Despite the fact that the project "Communitybased Approach to Local Development" had a clearly defined infrastructure nature, we assumed that perhaps the social mobilization of community residents was its even more significant achievement, which has led to the activation of the "dormant" potential of collective actions and the desire of people to help themselves. According to our hypothesis, the changes that occured at the mental level should result in the improvement in the social capital of communities in the nearest years after the end of the project.

We decided to test this hypothesis on the basis of the analysis of the development of those rural communities of Sumy region, which took part in the Phase I of the project "Community-based Approach to Local Development". 49 micro-projects were implemented in 33 communities in eight districts of Sumy region totalling over UAH 8.7 $\mathrm{mln}$. during the implementation of the first phase of the project "Community-based Approach to Local Development” (2007-2010) (www.cba.org. ua).

The difference-in-differences method was used (Girma \& Görg, 2007) to analyze the results of the Phase I of the project "Community-based Approach to Local Development". The essence of this method consists in finding the difference between the indicators of social capital of studied communities in 2007 and 2011, i.e., "before" and "after" the participation in the project "Communitybased Approach to Local Development".

Together with Tetyana Holets (CERGE-EI, Prague, Czech Republic), we developed (on the basis of the most commonly used methodologies in the world practice, such as Integrated Questionnaire for the Measurement of Social Capital worked out by the World Bank (2011), The World Values Survey (2011), The European Social Survey (2002) and The Social Capital Question Bank (2011)) the corresponding methodology and questionnaire, adapted to the study goals and specificity of interviewed households. The desire to compare the indicators of the social capital of domestic territorial communities with the indicators of local communities in other countries of the European Union and the whole world was an additional advantage of these methodologies usage.

The main components of social capital, which were measured during a sociological survey, are as follows: general norms (honesty, decency, etc.), trust, proclivity for interaction and cooperation, solidarity, (anti)paternalism, the availability of common traditions, long-term orientation, proclivity for risk, inclusion in the decision-making process, etc.

The study of social capital in the territorial communities was carried out within the framework of the grant No.12-0991 from the Economics Education and Research Consortium, Inc. (EERC) and the assistance of the central and regional offices of the project "Community-based Approach to Local Development" while conducting a large-scale survey of the territorial communities residents.

The sample group consisted of 126 territorial communities (33 territorial communities that participated in the Phase I of the project that provided the participatory financing and 94 territorial communities that were similar by development indicators to the studied territorial communities, but where the participatory financing was not implemented). The household in the territorial community was the smallest unit of the analysis. 1545 households were interviewed, which makes about $10 \%$ of their total number. 
Each component of social capital was estimated by a scale from 1 to 5 based on the respondents responses (household leaders) to a group of questions connected with this characteristic ( 1 is the lowest value, 5 is the highest value of the corresponding characteristic).

The communities-participants of the Phase II of project "Community-based Approach to Local Development", which had similar selection criteria in the initial phase of the project (pipeline matching aimed to deal with selection and self selection biases), were used as comparison communities while studying the impact of the participative financing mechanism of this project on the social capital of the communities-participants of the Phase I (Heckman et al., 1997). This allowed to avoid selection errors, as the methodology for selecting the participants in the Phase I and Phase II of the project "Community-based Approach to Local Development" remained practically unchanged. In the Phase II, only one selection criterion has changed comparing to the Phase I (i.e., the necessity of transporting the children of rural communities to school). But the factor analysis has shown that its impact on the selection of the project participants was minimal and it was excluded in the Phase II of the project "Communitybased Approach to Local Development", as all villages had the transportation to schools.

A comparison territorial community (a participant of Phase II), similar in terms of socio-economic development, was determined from the same territorial area for each participating territorial community in Phase I of the project "Communitybased Approach to Local Development", which provided the participatory financing.

The pipeline matching methodology supposes that territorial communities, selected for the Phase II of the project "Community-based Approach to Local Development" (as of 2011), are similar to the communities of the Phase I of the project at the time of their selection (i.e., as of 2007) (Khandker et al., 2010; Walker et al., 1999). Thus, the difference between the indicators of these communities shows the effect of participatory financing of projects of social and economic development of the project "Community-based Approach to Local Development" and, accordingly, it is possible to use the data on social capital obtained in 2011 for analysis.

49 micro-projects were implemented in $33 \mathrm{com}$ munities in eight districts of Sumy region totalling over UAH $8.7 \mathrm{mln}$. during the implementation of the Phase I of the project "Community-based

Approach to Local Development" (2007-2010). Our study covered 6 districts of Sumy region, whose communities were represented during the Phase I and Phase II of the project.

Specification of the general model of the study is as follows:

$$
\begin{gathered}
E_{P F}=S K_{2011}^{P F}-S K_{2011}^{\text {Contr }}, \\
\Delta S K_{i}^{P F}=\beta_{0}+\beta_{1} P F+\theta X+\varepsilon .
\end{gathered}
$$

where $E_{P F}$ - effect of the impact of participative financing on social capital of the territorial communities; $S K^{P F}$ - value of social capital in the territorial communities where the participative financing was implemented; $S K^{\text {Contr }}$ - value of social capital in the comparison territorial community; $\Delta S K^{P F}{ }_{i}$ - the change in the value of characteristic $i$ of social capital in the territorial community; $\beta_{0}-$ free coefficient of regression equation; $\beta_{1}$ - parameter of impact of participative financing on characteristic $i$ of social capital (shows the increase of characteristic $i$ of social capital, that is estimated by the scale from 1 to 5); $\theta$ - parameter of impact of other explanatory variables; $X$ - vector of other explanatory variables; $e$ - random error.

\section{RESULTS: PART 1}

The study of the impact of the participation in the project "Community-based Approach to Local Development" on the social capital of the territorial communities showed an increase of almost all characteristics of social capital (Tables 1-2). However, it should be noted that the comparison of the numerical values of the characteristics of the social capital of Ukrainian communities with the values of the European Union communities demonstrates the underrun by $20 \%$ of the characteristics of the social capital of Ukrainian communities compared to the communities of the European Union countries. 
Table 1. The average values of characteristics of social capital and their change as a result of the impact of participative financing ${ }^{1}$

\begin{tabular}{|c|c|c|c|}
\hline $\begin{array}{c}\text { Characteristics } \\
\text { of social } \\
\text { capital }\end{array}$ & $\begin{array}{l}\text { Communities } \\
\text { where the } \\
\text { participatory } \\
\text { financing was } \\
\text { implemented }\end{array}$ & $\begin{array}{l}\text { Comparison } \\
\text { communities }\end{array}$ & $\begin{array}{l}\text { Change } \\
(\Delta), \%\end{array}$ \\
\hline $\begin{array}{l}\text { Traditions in the } \\
\text { community }\end{array}$ & 3.337 & 3.065 & 8.871 \\
\hline $\begin{array}{l}\text { Information and } \\
\text { communication }\end{array}$ & 2.957 & 2.885 & 2.498 \\
\hline $\begin{array}{l}\text { Empowerment } \\
\text { and political } \\
\text { action }\end{array}$ & 2.443 & 2.410 & 1.392 \\
\hline $\begin{array}{l}\text { (Anti) } \\
\text { paternalism }\end{array}$ & 3.701 & 3.466 & 6.778 \\
\hline Level of trust & 2.966 & 2.940 & 0.857 \\
\hline $\begin{array}{l}\text { Solidarity and } \\
\text { inclusion }\end{array}$ & 3.531 & 3.514 & 0.484 \\
\hline $\begin{array}{l}\text { General moral } \\
\text { and cultural } \\
\text { norms }\end{array}$ & 3.808 & 3.783 & 0.660 \\
\hline $\begin{array}{l}\text { Collective } \\
\text { action and } \\
\text { cooperation }\end{array}$ & 3.276 & 3.162 & 3.604 \\
\hline
\end{tabular}

Table 2. The results of multivariate regression analysis of the impact of the participatory financing mechanism of the project "Communitybased Approach to Local Development" (20072011) on the characteristics of social capital (found on the basis of software package STATA)

\begin{tabular}{l|c}
\hline $\begin{array}{c}\text { Characteristics of } \\
\text { social capital }\end{array}$ & $\begin{array}{c}\text { Effect of impact of the } \\
\text { participatory financing } \\
\text { mechanism on the } \\
\text { characteristics of social capital } \\
\text { (treatment effect) }\end{array}$ \\
\hline $\begin{array}{l}\text { Traditions in the } \\
\text { community }\end{array}$ & $0.538^{* * *}$ \\
\hline $\begin{array}{l}\text { Information and } \\
\text { communication }\end{array}$ & $0.162^{*}$ \\
\hline $\begin{array}{l}\text { Empowerment and } \\
\text { political action }\end{array}$ & $0.256^{* * *}$ \\
\hline $\begin{array}{l}\text { (Anti)paternalism } \\
\text { Level of trust }\end{array}$ & $0.455^{* *}$ \\
\hline $\begin{array}{l}\text { Solidarity and } \\
\text { inclusion }\end{array}$ & $0.160^{*}$ \\
\hdashline $\begin{array}{l}\text { General moral and } \\
\text { cultural norms }\end{array}$ & $0.137+$ \\
\hline $\begin{array}{l}\text { Collective action and } \\
\text { cooperation }\end{array}$ & 0.094 \\
\hline
\end{tabular}

Notes: $+\mathrm{p}<0.10 ;{ }^{\star} \mathrm{p}<0.05 ;{ }^{* *} \mathrm{p}<0.01 ;{ }^{* * *} \mathrm{p}<0.001$

The results of the study of the impact of participatory financing on the social capital of territorial communities (Table 2) showed that the charac- teristics of social capital, such as the presence of traditions in community, awareness, (anti) paternalism, collective action and cooperation, are the most affected.

\section{METHODOLOGY: PART 2}

In 2014, with the assistance of the project "Community-based Approach to Local Development", another survey was conducted to determine the level of social capital in the territorial communities, where the mechanisms of the participatory financing and participatory management of financial resources were implemented in 2011 (45 rural territorial communities of Sumy region, which participated in the Phase II of the project "Community-based Approach to Local Development”).

The Phase II of the Joint UNDP/EU Project "Community-based Approach to Local Development" commenced on June 7, 2011 and ended at the end of 2015. The project was co-financed and implemented by the United Nations Development Program in Ukraine.

The overall goal of the Phase II of the project, which also provided the participatory financing and participatory management of financial resources, was to create an enabling environment for long-term social and economic development at the local level through the development of local self-government and support for initiatives aimed at the community development throughout Ukraine.

The specific goals of the Phase II of the project "Community-based Approach to Local Development" are as follows:

- promoting a community-based approach to local governance and sustainable development;

- improving energy efficiency at the local level;

- supporting the establishment of knowledge management centers for community mobilization and joint management and a network of best practices dissemination.

1 range of possible values of characteristics from 1 (the lowest value) to 5 (the highest). 
This phase of the project "Community-based Approach to Local Development" had a budget of 17.1 million euros $(98.4 \%$ was the contribution of the European Union and $1.6 \%$ was the contribution of the United Nations Development Program), which was aimed at supporting sustainable social and economic development at the local level (www. cba.org.ua).

The project was implemented in all regions of Ukraine. More than 900 communities received the opportunity to implement their initiatives during the Phase II of the project "Communitybased Approach to Local Development". The project supported community initiatives in the following fields:

- energy saving and energy saving technologies;

- water supply;

- healthcare;

- environmental protection;

- $\quad$ supporting small business (development of agricultural service cooperatives).

The general model of the study of the impact of participatory financing of micro-projects of the local development in the Phase II of the project "Community-based Approach to Local Development" was similar to the previous one (the assessment of the impact of participatory financing in the Phase I of the project). But, this time, we could not use pipeline matching, as we had data on the level of social capital in territorial communities both before and after the implementation of the participatory financ- ing of local development. As a basis for selection of comparison communities, the data on the level of social capital in 100 rural territorial communities of Sumy region, where the participatory financing wasn't implemented, were used (before the questionnaire of 2011 with the financial and organizational support of the project "Community-based Approach to Local Development" the additional questionnaire of the territorial communities residents was carried out in 2014).

Specification of the general model of the study is as follows:

$$
\begin{gathered}
E_{P F}=\left(S K^{P F}{ }_{2014}-S K^{P F}{ }_{2011}\right)- \\
-\left(S K^{\text {Contr }}{ }_{2014}-S K^{\text {Contr }}{ }_{2011}\right), \\
\Delta S K_{i}^{P F}=\beta_{0}+\beta_{1} P F+\theta X+\varepsilon .
\end{gathered}
$$

where $E_{P F}$ - effect of the impact of participative financing on social capital of the territorial communities; $S K^{P F}$ - value of social capital in the territorial communities where the participative financing was implemented; $S K^{\text {Contr }}$ - value of social capital in the comparison territorial community; $\Delta S K_{i}^{P F}-$ the change in the value of characteristic $i$ of social capital in the territorial community; $\beta_{0}$ - free coefficient of regression equation; $\beta_{1}$ - parameter of impact of participative financing on characteristic $i$ of social capital (shows the increase of characteristic $i$ of social capital, which is estimated by the scale from 1 to 5); $\theta$ - parameter of impact of other explanatory variables; $X$ - vector of other explanatory variables; $\varepsilon$ - random error.

Table 3. The outcomes of the multivariate regression analysis of the impact of the participatory financing mechanism of the project "Community-based Approach to Local Development" (2011-2014) on the characteristics of social capital (found on the basis of software package STATA)

\begin{tabular}{l|c}
\hline \multicolumn{1}{c}{ Characteristics of social capital } & $\begin{array}{c}\text { Effect of impact of the participatory financing mechanism on the } \\
\text { characteristics of social capital (treatment effect) }\end{array}$ \\
\hline Traditions in the community & $0.311^{* *}$ \\
Information and communication & $0.226^{* *}$ \\
\hline Empowerment and political action & $0.551^{* *}$ \\
\hline (Anti)paternalism & $0.603^{* * *}$ \\
\hline Level of trust & $0.152+$ \\
\hline Gelidarity and inclusion & $0.205^{*}$ \\
\hline Collective action and cooperation & $0.12+$ \\
\hline
\end{tabular}

Notes: $+\mathrm{p}<0.10 ;{ }^{*} \mathrm{p}<0.05 ;{ }^{* *} \mathrm{p}<0.01 ;{ }^{* * *} \mathrm{p}<0.001$ 


\section{RESULTS: PART 2}

The results of the study of the impact of the participatory financing on the social capital of the territorial communities, which participated in the second phase of the project "Community-based Approach to Local Development", are given in Table 3.

The data of Table 3 once again proved the significant positive impact of participatory financing on the indicators of the social capital of territorial communities. (Anti)paternalism, the availability of traditions, involvement in social activities, collective activities and cooperation are to be the most affected characteristics of social capital.

At the same time, the most modern scientists are inclined to the view that social capital is changing too slowly and cannot change in few years; sometimes it is necessary to change several generations living on the territory. Therefore, the results of the impact of the participation in the project "Community-based Approach to Local Development" on the indicators of the social capital of the communities participating in the project for rather short period (for several years) need an explanation.

\section{CONCLUSION}

The direct acquaintance with the methodology of the project "Community-based Approach to Local Development" and interviews with its participants suggest that the impact of this international project on the social capital of the local communities is manifested precisely because of the specific financial and organizational mechanism of the project.

This mechanism is based on the approach of using the economic potential of social mobilization to local development, implemented through the tools of the participatory concept of the financial policy of local development, i.e., participatory financing and participatory management of financial resources. During the participation in the project "Community-based Approach to Local Development", the members of the territorial community are united into a public organization in order to obtain the necessary financing, they also learn to make decisions together concerning the financial resources management, elect the chairman and the board of the organization, choose the priorities for the development of community, the project to be implemented, contractors for the work performance, control together the movement of financial resources and the performance of tasks. While implementing the micro-project, they begin to trust each other more; understand that they can solve problems themselves, and not rely only on state assistance; learn to make decisions jointly, work together. And, as a result, the traditions of collective actions and holidays, solidarity begin to be restored, paternalism decreases and trust grows.

In this case, we may talk not only about the increase in the communities' social capital, but also the implementation of its existing, but the "dormant" potential. Such implementation can occur in a relatively short period of time (in 4 years, as in the project "Community-based Approach to Local Development").

It is necessary to pay attention to the comments, received as a result of the study, concerning the qualitative change of the reasoning during the decision-making by the members of the communities participating in the project "Community-based Approach to Local Development", which probably explains the insignificant changes in the level of trust. A more detailed analysis showed that the mechanism of the project "Community-based Approach to Local Development" has impacted not only awareness, but also the participants' thinking. While assessing the level of trust in authorities, they take into account more factors and, as a result, an objective assessment of this characteristic of social capital can decrease.

At the beginning of the study, we assumed that the trust between community residents and government should significantly increase as a result of their joint activities during the implementation of local development projects. The results of the analysis did not confirm our assumption. The general level of trust 
of local communities has grown less than other components of social capital (0.152+). Besides, observations have shown that the level of trust in the institutions of authorities (the analysis of the answers to Question 14 of the questionnaire) has not only increased, but even has decreased in some communities. Interviews with the community residents explained this result by the fact that within the framework of joint activities the average members of the community were able to get to know the real mechanisms of the government's activities more closely, which were often associated with corruption. Accordingly, new more reliable knowledge about the activities of authoritis only reduced the trust in it.

\section{ACKNOWLEDGEMENT}

The research is performed within the framework of the scientific project "Development of scientific and methodological bases and practical tools of the financial policy of sustainable development of the united territorial communities".

\section{REFERENCES}

1. Butler, B., Pick, D., \& Dayaram, K. (2009). Social capital as "the missing link" in the growth process: implications for strategic orientation of businesses and sustainable regional development in a remote location. Problems and Perspectives in Management, 7(1), 40-48. Retrieved from http://businessperspectives.org/ journals/problems-and-perspectives-in-management/issue-24/ social-capital-as-the-missing-linkin-the-growth-process-implications-for-strategic-orientationof-businesses-and-sustainable-regional-development-in-a-remotelocation

2. Community-Based Approach to Local Development. Retrieved from www.cba.org.ua

3. Dongier, P., Domelen, J. V., Ostrom, E. et. al. (2011). Communitydriven development. In J. Klugman (Ed.) Poverty Reduction Strategy Paper Sourcebook (pp. 301331). Washington, D.C.: World Bank. Retrieved from http:// documents.worldbank.org/curated/ en/156931468138883186/Coretechniques-and-cross-cuttingissues

4. Fearon, J. D., Humphreys, M., \& Weinstein, J. M. (2009). Can development aid contribute to social cohesion after civil war? Evidence from a field experiment in post-conflict Liberia. American Economic Review: Papers \&
Proceedings, 99(2), 287-291.

Retrieved from http://www. columbia.edu/ mh2245/papers1/ aer2009.pdf

5. Girma, S., \& Görg, H. (2007). Evaluating the foreign ownership wage premium using a differencein-differences matching approach. Journal of International Economics, 72, 97-112. Retrieved from http:// faculty.smu.edu/millimet/classes/ eco7377/papers/girma\%20gorg.pdf

6. Hardin, G. (1968). The Tragedy of the Commons. Science. New Series, 162(3859), 1243-1248. Retrieved from http://science.sciencemag. org/content/162/3859/1243

7. Heckman, J., Ichimura, H., Smith, J., \& Todd, P. (1997) Matching as an econometric evaluation estimator: evidence from evaluating a job training programme. Review of Economic Studies, 64, 605-654. Retrieved from http://athena.sas.upenn.edu/ petra/papers/match.pdf

8. Khandker, S. R., Koolwal, G. B., \& Samad, H. A. (2010). Handbook on impact evaluation: quantitative methods and practices. Washington, DC: World Bank. Retrieved from https://openknowledge.worldbank. org/bitstream/handle/10986/2693/ 520990PUB0EPI1101Official0Use 0Only1.pdf

9. Kostyuchenko, N., Petrushenko, Yu., Smolennikov, D., \& Danko, Yu. (2015). Community-based approach to local development as a basis for sustainable agriculture: experience from Ukraine. International Journal of Agricultural Resources, Governance and Ecology (IJARGE), 11(2), 178-188. https://doi.org/10.1504/ IJARGE.2015.072901

10. Kumar, N. (2003). Communitydriven development: a study methodology. Operations Evaluation Department. Retrieved from http://siteresources. worldbank.org/EXTEFFWBSUPCOMDRIDEV/Resources/discussion_paper.pdf

11. Mansuri, G., \& Rao, V. (2004). Community based and driven development: a critical review. The World Bank Research Observer, 19(1), 1-39. Retrieved from http://web.worldbank.org/ archive/website01066/WEB/IMAGES/10650632.PDF

12. Olson, M. (1965). The logic of collective action: public goods and the theory of groups. Cambridge: Harvard University Press.

13. Sara, J., \& Katz, T. (1997). Making Rural Water Supply Sustainable: Report on the Impact of Project Rules. United Nations Development Programme and World Bank Water and Sanitation Program. Washington, DC: World Bank. Retrieved from http://documents.worldbank.org/curated/ 
en/495261468135922056/Makingrural-water-supply-sustainablereport-on-the-impact-of-projectrules

14. Tanaka, S., Singh, J., \& Songco, D. (2006). A review of community-driven development and its application to the Asian Development Bank. Manila: Asian Development Bank.

15. UNIAN Information Agency (2011). The number of rural population declined by 2.5 million. Retrieved from http://health. unian.net/ukr/detail/224241

16. Walker, I., Cid, R., Ordonez, F., \& Rodriguez, F. (1999). Ex-Post
Evaluation of the Honduran Social Investment Fund (FHIS 2). Tegucigalpa: ESA Consultores.

17. Walker, T. F. (2011). Community involvement in public goods provision: Evidence from a field experiment in Ghana. London: LSE, International Growth Centre. Retrieved from http://assets. publishing.service.gov.uk/media/57a08ae740f0b6497400083c/ Walker-2011-Working-Paper.pdf

18. Whiteside, K., \& Wassenich, P. (2004). CDD impact assessment study: optimizing evaluation design under constraints. Social Development Papers. Community driven development (51). Washington,
DC: World Bank. Retrieved from http://documents.worldbank.org/ curated/en/846641468782365825/ CDD-impact-assessment-study-optimizing-evaluation-design-under-constraints

19. World Bank (2005). Community driven development (CDD) and social capital impact : designing a baseline survey in the Philippines. Washington, DC: World Bank. Retrieved from http:// documents.worldbank.org/curated/en/318241468296447434/ Community-driven-development-CDD-and-social-capitalimpact-designing-a-baselinesurvey-in-the-Philippines 